\title{
The European Monetary System: An Approach to Regional Economic Integration
}

\author{
Peter Schaal*
}

\section{INTRODUCTION}

The European process of economic integration started under political premises. After World War II Winston Churchill in a speech given in Zurich on September 19, 1946, proposed the formation of the "United States of Europe" as a political means to overcome old hostilities and to start a new era of political cooperation and economic integration among European nations. In 1950 Robert Schuman, the French foreign minister, took the initiative to propose the creation of a common coal and steel market between France and Germany that was open for membership to other European nations. This idea led to the establishment of the "European Community for Coal and Steel (ECCS) as a sectoral economic integration among France, Germany, Italy, Belgium, Luxembourg, and the Netherlands; the agreement was signed on April 18, 1951, and took effect in May 1952. The logical extension of this partial integration of two basic industries was a general economic integration by the creation of an economic union. This took place when the six member states of the ECCS signed the treaty of the European Economic Community (EEC) on March 25, 1957, effective on January 1, 1958.

According to Article 237 of the EEC Treaty, the community was open to other European states. The European executive institutions of ECCS, EEC, and the European Atomic Community were merged in July 1967 and are referred to as the European Communities (EC). Over time the newly created larger European Common Market lured other European states to join it: Great Britain, Ireland, and Denmark on January 1, 1973, and Greece on January 1, 1981; Portugal on March 28 and Spain on July 28, 1977, applied for membership.

The European Free Trade Association (EFTA), now consisting of Austria, Finland, Iceland, Norway, Portugal, Sweden, and Switzerland, has concluded a free trade agreement with the EC effective on January 1 , 1980. With other countries the EC negotiated bilateral agreements of association as well as bilateral and multilateral preferential trade

\footnotetext{
*Dr. Peter Schaal is a visiting Fulbright professor of economics from Fachhocschule (University College) Dusseldorf, Germany, at The University of Alabama. An earlier version of this paper was presented to the Institute on Western Europe, Columbia University on November 5, 1981.
} 
agreements. The most important trade agreement on a multilateral basis is that of Lomé II by which the EC granted unilateral import preferences to fifty-six ACP (Africa, Caribbean, Pacific) countries to give them access to the European Common Market in connection with direct development aid and the establishment of a stabilization fund for their exports of tropical products (Stabex). The negotiations for this Lomé treaty took almost six years, until the end of 1980 .

Articles 103 to 109 of the EEC treaty stated in general terms that the economic integration into a common market was to be accompanied by a monetary integration. With the progress of economic integration abolishing all internal customs tariffs and other trade barriers and establishing a common external tariff vis-à-vis the rest of the world (called "third countries") on January 1, 1968, it became evident that monetary integration was necessary to stabilize the customs union and to foster the integration process. Consequently it appeared imperative to create a monetary union congruent to the customs union.

Several efforts had been undertaken to start a monetary union. They failed because of external deterioration of the currency markets or because of internal discrepancies in monetary policies. The latest structure of a monetary union is the European Monetary System (EMS), which ought to be the monetary counterpart of the Common Market of the EC. It is meant to create a stable currency area in the EC and a powerful monetary bloc in the world to contribute to the stabilization of the world monetary system.

This article will examine how realistic these targets of the EMS are and to what extent the development of exchange rates in the EMS during its two and a half years of existence were compatible with them.

\section{HISTORY OF THE APPROACHES TO MONETARY INTEGRATION IN EUROPE}

\section{The Bretton Woods Era}

In the era of the Bretton Woods monetary system from July 1944 to August 1971, all currencies were pegged to each other by fixed exchange rates via a fixed parity to the US dollar, which in turn had a fixed parity to gold. This gold parity was set as $\$ 35.00$ per fine ounce of gold, and with later depreciations of the dollar, as $\$ 38.00$ (December 21, 1971) and $\$ 42.22$ (February 14,1973) per ounce of gold. The market rate of currencies was allowed to float only by 0.5 percent above or below parity and was to be defended by unlimited interventions by the central banks to stay within this margin.

The world monetary system broke down because the United States could no longer keep its promise to exchange into gold any amount of U.S. dollars produced by permanent U.S. balance of payments deficits and held by foreign central banks. The increasing world distrust in the economic background, purchasing power, and stability of the dollar caused heavy 
speculations against it. Therefore, President Nixon declared the abolishment of the convertibility of the dollar into gold, thus terminating the Bretton Woods system on August 11, 1971. Before the breakdown of the Bretton Woods system the presidents of the EC central banks signed an agreement on February 2, 1970, to set up a system of mutual short-term assistance with foreign exchange as a first step toward monetary cooperation.

\section{Again Fixed Parities}

The Smithsonian Agreement on December 18, 1971, in which new parities were fixed on the basis of those exchange rates as formed by the market forces in the free float was an attempt to rescue the system of fixed parities after a period of free floating. At the same time, a larger floating margin of 2.25 percent above or below parity was provided. But the distrust against the U.S. dollar prevailed, forcing its further depreciation and the final abolishment of the fixed parity system by allowing a free floating of all currencies against the dollar since March 19, 1973.

\section{An Approach to Monetary Integration in the EC}

Free floating or even a large floating margin above and below fixed parities is not compatible with any economic union of countries wanting to keep a common market working. The idea to form a monetary union as a means to foster further progress in the integration process of the European Common Market was discussed in the 1960s. One group of economists and politicians, largely from France and Belgium, called Monetarists (not to be confused with the monetary theory of the same name) wanted to accelerate the creation of a monetary union in the EC by durable fixed parities between the currencies of the member countries, an installation of a common central bank similar to the U.S. Federal Reserve System, the pooling of foreign exchange reserves, and a common monetary policy. They expected this monetary integration to give impetus to an automatic and faster process of economic integration. The Monetarists were opposed by another group of economists and politicians, mainly from Germany and the Netherlands, called Economists who demanded a coordination of economic policy targets and means as a precondition for further monetary integration.

The outcome of this intellectual debate was the Parallel Principle with "Crowning Theory": monetary as well as economic integration ought to be developed in a parallel, step-by-step approach until a new common European currency in the end "crowns" the integration process. On this basis and by order of the European "summit meeting" in November 1969, the Werner Plan to establish a European economic and monetary union was elaborated and approved by the European Council on March 22, 1971. It provided an accelerated integration process in three steps during three years and consisted of three sets of economic and monetary policy measures starting in January 1971: 
- Cooperation in monetary policies to progressively reduce the margin above and below parities until fixed and unchangeable parities would be reached as a basis of a common EC currency with a common central bank after 1980 .

-A coordinated economic policy on the basis of common guidelines and targets to prevent structural disequilibria among the balance of payment of the member countries.

- Transfer payments to regions with a structural economic weakness to prevent a decrease of the standard of living in those regions as a consequence of the integration process.

\section{The "Snake in the Tunnel" of European Currencies}

Shortly after the implementation of the first step of the Werner Plan, distortions in the world currency markets stopped all further progress after May 1971. As a short-term substitute the European Council created a currency union with fixed parities and a smaller margin of only 1.125 percent above and below parity compared with a broader margin of \pm 2.25 percent between all currencies of the world in the Smithsonian Agreement. Belgium, Luxembourg, Germany, France, Italy, Great Britain, the Netherlands, and Denmark (as a prospective member of the EC in the coming year) became members of this monetary bloc. As membership was offered to other European nations, Norway and Sweden joined the European monetary bloc and its "bloc floating" within the limits of the broader margin allowed to all other currencies. The "snake in the tunnel" was born.

Because of divergent economic and monetary developments in the participating countries and unsuccessful policies to stabilize their economies, one after the other broke away: Italy, France, Sweden, Norway, and Great Britain with Ireland. Only a "mini-snake" remained in 1978; it consisted of Germany, the Netherlands, Belgium, Luxembourg, and Denmark and was dominated by the strong German currency. Thus this experiment in European monetary integration had failed.

To start a new effort toward European monetary integration with more stringent rules by political decision, three "summit meetings" were held and resulted in the creation of the European Monetary System (EMS). It was designed to comprise the currencies of all EC member countries as a congruity to the Common Market but also open to other European countries on the basis of an agreement between central banks.

\section{THE MECHANISM OF THE EUROPEAN MONETARY SYSTEM}

\section{The Purpose of a European Monetary Union}

The EMS was meant to induce the EC member countries to a higher degree of monetary discipline to keep fixed exchange rates between the currencies of the EMS as a basis for a further progress in intra-EC trade without currency risks. The economic targets of the EMS are summarized 
by the conclusions of the president of the European Council of December 4-5, 1979:

The purpose of the European Monetary System is to establish a greater measure of monetary stability in the Community. It should be seen as a fundamental component of a more comprehensive strategy aimed at lasting growth with stability, a progressive return to full employment, the harmonization of living standards, and the lessening of regional disparities in the Community. The European Monetary System will facilitate the convergence of economic development and give fresh impetus to the process of European Union. The Council expects the European Monetary System to have a stabilizing effect on international economic and monetary relations. It will therefore certainly be in the interests of the industrialized and the developing countries alike. ${ }^{2}$

The governments of the EMS member countries envisaged that this monetary system should contribute internally in the EC to a "convergence in economic development," to reach a political and economic "European Union," and externally between EC and third countries to a stabilization of economic and monetary relations. We will investigate how far this appears to be probable and how it has worked until now. But first a short outline of the main features of the EMS effective since March 13, 1979, will be given.

\section{The Features of the EMS}

The prevailing monetary imbalance in the European Common Market was considered to be the cause for a rising unemployment rate, a decreasing propensity to invest, and a shrinking volume of intra-EC trade. ${ }^{3}$ To fight monetary imbalance the new EMS was based on fixed parities that should be maintained by a coordinated monetary and economic policy to get the same inflation rates on a very low level. If a fundamental disequilibrium existed between currencies of the EMS, however, a change of parities as a measure of correction was provided on the basis of "fixed but accommodable rates of exchange."

The EMS is based on five elements:

- the European Currency Unit (ECU)

-fixed parities with the possibility to change them

common exchange rate policies vis-à-vis currencies of third countries

- a common "European Fund for Monetary Cooperation"

- the European Investment Bank (EIB)

The newly created ECU is an artificial currency defined as a "basket" of fixed amounts of the nine currencies of the EC member countries. ${ }^{4}$ It goes back to the "European Unit of Account" (EUA) created June 28, 1974, by the European Council in parity with the Special Drawing Right (SDR). The EUA was equivalent to a "basket" of the nine currencies of the EC member countries weighed statistically with the percentage share of (a) each coun- 
try in intra-EC trade, (b) GNP share of each country from the EC GNP total, and (c) the quota each country had received in the system of mutual currency support that had been agreed upon among EC member states in February 1970. Taking any currency out of this "basket of currencies" as the unit of reference, for example, the German D-mark with the parity of 1 EUA $=1 \mathrm{ECU}=2.5082 \mathrm{DM}$ on March 13, 1979, one gets the fixed amounts of each currency by multiplying this DM amount with the percentage weight and the rate of exchange of each currency according to Table $1 .^{5}$

In the EMS agreement it was provided that the weights of the currencies in the "basket" could be revised within six months after the EMS took effect and thereafter every five years or on request of a member if the weight of its currency had changed by 25 percent. Revisions have to be mutually accepted by all members and would not necessarily modify the external value of the ECU or of single currencies of the EMS.

The ECU plays a central role in the EMS and is used as a:

- denominator or "numèraire" (Leon Walras) for the exchange rate mechanism

-basis for the divergence indicator

- denominator for operations in the intervention and credit mechanisms

- means of settlement between the monetary authorities in the $\mathrm{EC}^{6}$

The parity (or indicator standard value) as well as the maximum and minimum rates of exchange of each currency are expressed in ECU, and the parities between the EMS currencies are calculated as cross-rates over

TABLE 1

EC: The EMS Currency Basket

\begin{tabular}{lrccc}
\hline \multicolumn{1}{c}{ Currency } & $\begin{array}{c}\text { Weight } \\
\text { in \% }\end{array}$ & $\begin{array}{c}\text { Equivalent } \\
\text { in DM }\end{array}$ & $\begin{array}{c}\text { Rate of Exchange in } \\
\text { DM on Feb. 15, 1979 }\end{array}$ & $\begin{array}{c}\text { Fixed Amount } \\
\text { of Currency }\end{array}$ \\
\hline $\begin{array}{c}\text { DM } \\
\text { British Pd. }\end{array}$ & 33.01 & 0.8280 & - & 0.8280 \\
in Sterling & 13.10 & 0.3285 & 3.712 & 0.0885 \\
$\quad$ FF & 19.87 & 0.4984 & 0.43335 & 1.15 \\
Lit & 9.62 & 0.2410 & 0.002211 & 09.0 \\
hFl & 10.55 & 0.2646 & 0.92515 & 0.286 \\
FB & 9.26 & 0.2323 & 0.06348 & 3.66 \\
Flux & 0.35 & 0.0089 & 0.06348 & 0.14 \\
Dkr & 3.12 & 0.0783 & 0.36085 & 0.217 \\
Irish Pd. & & & & \\
in Sterling & 1.12 & 0.0282 & 3.712 & 0.00759 \\
\hline & & & \\
1 EUC & 100.00 & 2.5082 & & \\
\hline
\end{tabular}

The weight is calculated each day as the percentage share of the fixed amount of each currency from its ECU parity. Source: Peter Schaal, Monetäre Theorie und Politik (Munich-Vienna: R. Oldenbourg Verlag, 1981), p. 89. 
ECU parities. Thus a parity grid of exchange rates between each currency with each other currency of the EMS indicating maximum and minimum rates is established.

\section{The Defense of Fixed Parities}

The deviation margin from parity was set at \pm 2.25 percent thus determining the intervention points or maximum and minimum rates of exchange for each currency. As an exception a broader margin of \pm 6 percent was granted to Italy for some time of transition whereas Great Britain abstained from joining the EMS for the time being.

Because the weight of each currency according to its relative importance is different in the EMS, a "maximum spread of divergence" was installed for each currency, taking into account its weight and therefore being smaller than the total margin. If the weight of the D-mark, for example, is 33.01 percent, its maximum spread of divergence is calculated as follows:

$$
\frac{2.25 \cdot(100-33.01)}{100}= \pm 1.5073 \text { percent. }
$$

To detect divergencies between EMS currencies, a "threshold of divergence" is fixed at 75 percent of a currency's "maximum spread of divergence." This in the case of the $\mathrm{D}$-mark is only \pm 1.1305 percent because of its high weight in the "currency basket." The "threshold of divergence" is used as an indicator for monetary and economic policy measures to be taken to restore equilibrium on the exchange markets if the rate of exchange rests there or exceeds the "threshold" for several weeks. These measures should be taken by the following sequence of rising intensity:

—diversified interventions

- measures of domestic monetary policy

- change of parities (central rates)

-other measures of economic policy

To defend the fixed parities within the "maximum spread of divergence" the central banks of the EMS member countries are obliged to conduct unlimited and "symmetrical" interventions predominantly with EMS currencies at the same time and in the same directions. Currencies of third countries, like the U.S. dollar, are also admitted for interventions. ${ }^{7}$ In fact, the most interventions were made in dollars. A coordinated exchange rate policy and a coordination of monetary policies with third countries is agreed to retain "orderly market conditions." That means that the central banks of the EMS member countries should deal by coordinated actions in the currency markets to prevent erratic short-term changes of their regional currency bloc against other important currencies of third countries, especially against the U.S. dollar. 


\section{A Common European Monetary Fund}

To make this system workable, a European Fund for Monetary Cooperation was founded by the supply of 20 percent of gold and 20 percent of foreign exchange reserves from the central banks of the EMS member countries. By so doing, a short-term "monetary support" of 14 billion ECU and a medium-term "financial assistance" of 11 billion ECU was created. Because of the rise of the gold price the value of the gold reserves grew by 75 percent until the end of August 1981, and thus the ECU liabilities of the fund grew to ECU 45.5 billion.

The short-term "monetary support" has a maturity of three months and can be extended twice by three months. It serves to finance interventions in the currency markets if a country runs short of foreign exchange necessary for large-scale interventions to support its currency. The medium-term "financial assistance" has a maturity of two to five years for financing a member country balance of payments deficit but will be given only if stringent economic policy measures are taken by the country to reduce the deficit. In a later step this "European Fund for Monetary Cooperation" should be transferred to a European Monetary Fund with higher financial means and sovereignty, with pooled reserves of the member countries, and acting as a common central bank. In this fund the ECU is to take a stronger position as the principal reserve asset in the EMS also to be used by other central banks outside the EMS, as the only means of payment to equalize balances of payment, and as a parallel currency.

As a supplementary institution of the EMS, the European Investment Bank (EIB) is designed to strengthen the economic potential of the less prosperous EC countries by loans of up to 1 billion ECU per year and per country in five annual drawings of 200 million ECU with an interest rate subsidy of 3 percent. Loans of the EIB are an instrument of regional policy and should contribute to a reduction of regional imbalances.

\section{STRUCTURAL DEFEGTS OF THE EMS}

\section{Asymmetrical Interventions}

The structure of the EMS is based on the expectation of a convergence of noninflationary economic policies of the member countries. This is a promise or hope as confirmed by the EMS treaty and the "Program of Policy Coordination"8 as agreed upon by the European Council in December 1980. But in practice the economic and monetary policies are still considerably divergent. There is no built-in rule in the EMS to enforce such coordinated policies.

The interventions of all central banks in the EMS did not work satisfactorily because interventions in support of an EMS member with weak currency had worse effects for this country by necessitating the sale of foreign exchange reserves and a restrictive monetary policy than interventions of a country with a strong currency, where additional liquidity was created to foster economic expansion. ${ }^{9}$ 
Thus, the central banks of EMS countries with a weak currency intervened in the currency markets with insufficient amounts to support their own currencies. Countries such as Belgium, Denmark, and Italy left the burden of interventions to other central banks of countries with stronger currencies (especially to the German Bundesbank) to stabilize their weak currencies.

Also, a weaker position of the U.S. dollar initiated dollar short-term capital imports to Germany, which led to a stronger position of the D-mark in the EMS and an even weaker position of the already weak EMS currencies because, with the rising strength of the D-mark, weak EMS currencies turned to D-mark assets. Since the D-mark consequently reached its upper "threshold of divergence" sizable unilateral DM interventions had to be performed. This meant the German Bundesbank had to purchase Italian lire, French francs, Belgian francs, and Danish kroner for D-marks and U.S. dollars (asymmetric interventions).

In the third quarter of 1980, interventions with U.S. dollars in favor of the declining Italian lira in the EMS coincided with a downward trend of the U.S. dollar rate of exchange vis-à-vis the EMS regional currency bloc. Thus, the additional supply of U.S. dollars to the money markets worsened the situation rather than stabilizing the exchange rates. It should also be observed that interventions in a certain currency create an additional money supply in that country, with an inflationary impact.

\section{Lack of Proper Devaluations}

Another built-in defect of the EMS favoring inflation is the hesitancy of governments to devalue their currency within the EMS for political reasons. The Belgian franc, for example, was supported by interventions in 1979 and 1981 despite the economic necessity of devaluation. It had been feared that a devaluation of the Belgian franc would not be efficient because of the malfunction of its price mechanism. ${ }^{10}$ The advantage of devaluation for Belgian exports would have been offset within a short time by rising import prices and their effect on indexed wages, costs, and prices.

There is also no mechanism to inforce a change of parity early enough and by a sufficient percentage rate. Further, the EMS lacks a mechanism to force countries with higher and rising inflation rates to adopt a restrictive monetary and economic policy. This defect in the construction of the EMS is considered an "engine of inflation."

\section{Statistical Weight of Currencies and the Role of Gold}

Another defect of this system is the method of calculating currency weights in the ECU "basket." Because fixed amounts of each currency are given in the "basket" to calculate the parity of each currency, the weight of each currency varies with changes of the ECU parity. That means that the weight of a currency changes with its increasing strength or weakness in the EMS and not according to its importance in the EC as originally calculated by its share of EC GNP, intra-EC trade, and quota in the European Fund for Monetary Cooperation. 
The role of gold as a reserve asset is not identified in the EMS. Certainly it was appropriate to establish the European Fund for Monetary Cooperation by pooling 20 percent each of gold and other reserves of the EMS member countries because gold no longer has an official price as a reserve asset. But the future role of gold in the EMS is still uncertain. While the French like to retain gold as an official reserve asset, the International Monetary Fund already has demonetized it.

In the fall of 1981 several proposals were made to restore the monetary properties of gold. Robert A. Mundell ${ }^{11}$ wants to stabilize the world monetary system by returning to a gold standard; Arthur B. Laffer and Charles W. Kadlec believe that people would demand more money for holding more dollar cash balances if they could be sure of its value. ${ }^{12} \mathrm{~A}$ return to the gold standard does not appear to be feasible because of:

- The high volatility of the gold price from $\$ 200$ to $\$ 800$ between 1979 and $1981 .^{13}$

-The growing scarcity of gold: gold reserves (valued by constant $\$ 35$ per ounce) rose from $\$ 34,550$ million in $1949^{14}$ to $\$ 37,185$ million in $1970^{15}$ and decreased to $\$ 32,833$ in $1981 /$ I. ${ }^{16}$ During the same period foreign exchange reserve grew from $\$ 15.9$ million in $1949^{13}$ to $\$ 44,530$ million in $1970^{15}$ to $\$ 370,897$ million in $1981 / \mathrm{I}^{16}$

- Russia which, as the world's second greatest gold producer, can influence gold markets and prices according to its economic and political needs.

Because the gold holdings and their share of total reserves are very different in the various EMS member countries, difficulties certainly will arise if all reserves of the member countries are to be pooled in a future common European Central Bank.

\section{STRUCTURAL DIFFERENCES AMONG EC COUNTRIES}

\section{Different Shares of Sectors}

The EC countries are far from what Robert H. Mundell calls an "optimum currency area." Economic differences between EC countries are evident in Table 2 by the different percentage shares of the labor force employed by the three sectors of the economy in $1979 .{ }^{17}$ The share of people working in agriculture varies considerably, especially among EC countries with a very high statistical spread and standard deviation. The average share of people working in agriculture in the EC is three times higher than in the U.S. Problems will arise with the entrance of Greece to the EC because 30.8 percent of its labor force works in agriculture. Member countries with a high share of agriculture are net receivers of transfer payments by the common agricultural policy. 
TABLE 2

EC: Employment By Sectors

\begin{tabular}{lccc}
\hline \multicolumn{1}{c}{$\begin{array}{c}\text { Employment by } \\
\text { sectors (percent 1979) }\end{array}$} & Agriculture & Industry & Services \\
\hline Belgium & 3.2 & 36.7 & 60.7 \\
Denmark & 8.3 & 30.2 & 61.5 \\
France & 8.8 & 36.3 & 54.9 \\
Germany & 6.2 & 44.9 & 48.9 \\
Great Britain & 2.6 & 39.9 & 58.4 \\
Greece & 30.8 & 30.0 & 39.2 \\
Ireland & 21.0 & 31.9 & 47.1 \\
Italy & 14.8 & 37.7 & 47.5 \\
Luxembourg & 6.1 & 44.7 & 49.2 \\
Netherlands & 4.8 & 32.7 & 62.4 \\
\hline EC Average & 10.66 & 36.5 & 52.98 \\
\hline Spread & 8.57 & 5.18 & 7.34 \\
Standard Deviation & 9.03 & 5.46 & 7.74 \\
\hline USA & 3.6 & 31.3 & 65.1 \\
\hline
\end{tabular}

Source: Europe, no. 223, Jan.-Feb. 1981, p. 16.

TABLE 3

EC: Changes in Employee Compensation, Productivity, and Labor Costs, 1970-1980

(Annual Percentage Rates of Change)

\begin{tabular}{|c|c|c|c|c|c|c|}
\hline & \multirow{2}{*}{$\begin{array}{l}\text { Compensation } \\
\text { per employee } \\
\text { in national } \\
\text { currency }\end{array}$} & \multirow{2}{*}{$\begin{array}{l}\text { Productiv- } \\
\text { ity (per } \\
\text { employee) }\end{array}$} & \multicolumn{2}{|c|}{ in national currency } & \multirow[b]{2}{*}{$\begin{array}{c}\text { Effective } \\
\text { Exchange } \\
\text { Rate }\end{array}$} & \multirow[b]{2}{*}{$\begin{array}{l}\text { Relative } \\
\text { labor costs } \\
\text { in U.S. } \$\end{array}$} \\
\hline & & & $\begin{array}{c}\text { Labor cost } \\
\text { per unit of } \\
\text { output }\end{array}$ & $\begin{array}{l}\text { Relative } \\
\text { labor } \\
\text { costs }\end{array}$ & & \\
\hline Belgium & 12.4 & 5.6 & 6.5 & -1.3 & 2.2 & 0.8 \\
\hline Denmark & 13.1 & 4.6 & 8.1 & -0.4 & 0.2 & -0.2 \\
\hline France & 13.3 & 4.2 & 8.7 & 0.6 & -0.2 & 0.4 \\
\hline Germany & 9.2 & 3.7 & 5.3 & -3.0 & 5.2 & 2.0 \\
\hline Great Britain & 17.6 & 2.1 & 15.2 & 7.3 & -3.1 & 4.0 \\
\hline Ireland & 18.2 & 2.8 & 14.9 & 4.6 & -3.2 & 1.2 \\
\hline Italy & 18.4 & 3.4 & 14.5 & 6.7 & -6.5 & 0.2 \\
\hline Luxembourg & 10.8 & 1.9 & 9.4 & - & - & - \\
\hline Netherlands & 11.1 & 4.6 & 6.2 & -1.7 & 2.8 & 1.0 \\
\hline $\begin{array}{l}\text { EC (weighted } \\
\text { average) }\end{array}$ & 13.2 & 3.8 & 9.1 & 2.4 & 0.6 & 3.0 \\
\hline
\end{tabular}

Source: European Economy, March 1981, p. 91. 


\section{Different Inflation Rates}

Another feature impeding an optimum currency area in the EC is what Alexandre Lamfalussy calls the "propensity to inflate." 18 Different attitudes toward what is considered a "bearable inflation rate," different anti-inflation policies of governments and central banks, different inflationary financing of public debt, and different rigorous and competing trade unions set a different pace of inflation in the various EC countries.

Comparing the average changes in labor costs in the last decade per country with the average change of productivity and effective exchange rates in Table $3^{19}$ reveals sizable differences of wage-push inflationary impact between countries. These are corrected to some extent by the effective exchange rates. Labor costs in Belgium rose only by the 2.2-fold of productivity whereas in Great Britain this relation was the 8.4-fold.

In the last decade all EC countries except Denmark had an average increase in their relative labor costs in dollars. Germany, Belgium, and the Netherlands suffered a higher effective appreciation of their currencies than the decrease of their relative labor costs could compensate. Denmark and France averaged only a slight change in the effective exchange rate and in relative labor costs. In Ireland, Italy, and Great Britain relative labor costs rose higher than the depreciation of their currencies could compensate, but in the case of Italy only with a very slight effect. This overshooting or undershooting of relative labor costs change by the effective exchange rate change is to be further explained by economic and speculative factors.

The propensity of a national economy to inflate can be recognized by the monetary targets that explain inflation roughly as the differential between the expansion rate of money supply and real economic growth the central bank of a country is willing to finance in the coming year. Subsequently it can be determined how far the money supply overshot the target and, in fact, financed inflation.

\section{Different Monetary Targets and Policies}

As a technique to control monetary expansion in EMS countries, all countries except Belgium, Italy, and Greece publish targeted monetary expansion rates for the coming year. In Belgium the exchange rate is the major target. Italy publishes a target limit for the expansion of domestic bank credit. "Intended as they are to help moderate inflationary expectations, the published targets for monetary expansion have normally been lowered from time to time, as in France, Germany, Canada, the USA, and Japan." 20

To a varying degree there is a conflict in all EMS countries to hold the monetary targets and to keep the exchange rate within the band above and below the fixed parity. For instance, a speculative capital flow from U.S. dollars to D-marks would require the German Federal Bank to intervene in the currency market and to buy dollars against D-marks not only to "smooth" changes of the dollar rate of exchange but also because D-marks 
will become stronger in the EMS and approach the upper intervention point there. This causes the money supply to increase and overshoot the monetary target. The German Federal Bank, therefore, must immediately apply restrictive monetary measures to absorb the money it previously had created by interventions.

Four examples will show different monetary targeting of European central banks that supply money in a more or less generous way. Germany controls central bank money. The targeted margin for 1980 was a spread from 5.0 to 8.0 percent, and 4.9 percent was reached. The target for 1981 is a spread of 4.0 to 7.0 percent. France controls $\mathrm{M}_{2}$ (cash, checking, and time deposits) targeted at 11.0 percent in 1980 while 9.8 percent was realized. In 198110.0 percent is the envisaged objective. Italy, controlling the total credit expansion rate set a target with 17.5 percent (expressed quantitatively in an upper ceiling of Lit. 59,000 billion), in 1980 performed with a rate of 18.6 percent. The target for 1981 is fixed at 16.0 percent. Finally, Great Britain, not yet a member of the EMS, controls the Sterling- $\mathrm{M}_{3}$ aggregate (cash and all bank deposits) and targeted a spread of 7.0 to 11.0 percent in 1980 but in fact reached an expansion rate of 19.4 percent. In 1981 a lower target of 6.0 to 10.0 percent is set. $^{21}$

\section{Different Fiscal Deficits}

Although there is no general fixed relationship between government borrowing and rates of monetary expansion, inflation, interest rates, foreign exchange, and external imbalance, large borrowing requirements of the government will always push up interest rates if combined with a tight monetary policy, as in the U.S. at present. If government borrowing takes place abroad in a sizable volume, there will be an increase in the balance of payments deficit and a downward pressure on the rate of

\section{TABLE 4}

EC: Central Government Net Borrowing Requirement In Percent of GNP ( $-=$ Borrowing), 1979-1981

\begin{tabular}{lccc}
\hline & 1979 & 1980 & 1981 \\
\hline Belgium & -6.9 & -9.0 & -9.2 \\
Denmark & -5.0 & -4.7 & -5.0 \\
France & -1.6 & -1.2 & -1.4 \\
Germany & -2.9 & -3.5 & -3.4 \\
Great Britain & -3.9 & -4.8 & -3.8 \\
Ireland & -13.9 & -14.5 & -13.3 \\
Italy & -10.9 & -10.6 & -9.5 \\
Luxembourg & 0.1 & -1.1 & -2.5 \\
Netherlands & -4.4 & -4.8 & -5.3 \\
\hline EC & -4.2 & -4.5 & -4.3 \\
\hline
\end{tabular}


exchange, as in Germany in 1980. If government borrowing is domestically eased by an expansionary monetary policy, the inflation rate will rise, which will also give pressure toward depreciation of the currency, as at the present time in Italy. Thus changes in the rates of inflation and exchange will depend on the absolute volume and the relative share with respect to GNP of government borrowing.

Looking at the relative size of central government net borrowing requirement in percent of GNP from 1979 to estimate 1981 in Table 4, one can see that excessively high levels of public debt (that is, only that of the central government) were reached and are maintained by Belgium, Ireland, and Italy in the range of 9 to 13 percent of GNP..$^{22}$ But Denmark, Germany, Great Britain, and the Netherlands also moved to sizably high levels between 3.4 and 5.3 percent of GNP. In those countries where this negative influence on inflation and exchange rates could not be compensated by other positive factors like an improvement of the balance of payments, as typical in Belgium, Italy, and Ireland, it contributed considerably to a depreciation pressure of their currencies in the EMS.

\section{Different Reactions to Exogenous Impacts}

The international competitiveness of a national economy, as well as its reaction to exogenous impacts, such as the two "oil price shocks" of 1973 and 1979, is mirrored in the development of its balance of payments. A comparison of the components of the balance of payments over the last three years between the nine EC countries in Table 5 reveals how far the countries succeeded in covering their deficit on current account by capital imports. ${ }^{23}$

All countries showed the effect of the oil price increase on their current accounts in 1979. All but France and Italy slid into a deficit. In 1980 France and Italy suffered a considerable deficit, too, and Belgium-Luxembourg and Germany could not prevent their deficit from increasing. Denmark, Ireland, and the Netherlands stabilized their deficit more or less at the level of the previous year while Great Britain turned to a surplus because it gained a high degree of self-sufficiency in energy supply with its North Sea oil. The success of the countries in compensating their current account deficit by capital imports (shown as a positive figure on their capital account) varied widely. Belgium-Luxembourg, Denmark, France, Ireland, Italy, and the Netherlands got net capital imports to compensate for the current account deficit. Germany's net capital imports were based on sizable governmental borrowing abroad (especially from Saudi Arabia) but were not sufficient to cover the high current account deficit. Consequently the total balance of payments deficit rose from 2.4 billion dollars in 1979 to 15.1 billion dollars in 1980 or from 0.31 percent to 1.82 percent of GNP. Great Britain lost capital by net exports, thus turning a surplus of 0.34 percent in 1979 into a deficit of 0.44 percent of GNP in 1980 (total external transactions). These capital outflows were caused by a slow-down of domestic economic activity and the acquisition of foreign securities bear- 
TABLE 5

EC: Balances of Payments, 1978-1980

\begin{tabular}{|c|c|c|c|c|c|}
\hline \multirow[b]{2}{*}{ Country } & \multirow[b]{2}{*}{ Years } & \multicolumn{4}{|c|}{ Net External Transactions in Billions of Dollars } \\
\hline & & $\begin{array}{l}\text { Current } \\
\text { Account }\end{array}$ & $\begin{array}{l}\text { Capital } \\
\text { Account }\end{array}$ & $\begin{array}{l}\text { Balancing } \\
\text { Item }\end{array}$ & Total \\
\hline Belgium- & 1978 & -0.9 & 0.2 & 0.4 & -0.3 \\
\hline \multirow[t]{2}{*}{ Luxembourg } & 1979 & -3.3 & 2.4 & -0.3 & -1.2 \\
\hline & 1980 & -5.9 & 5.8 & 0.5 & 0.4 \\
\hline \multirow[t]{3}{*}{ Denmark } & 1978 & -1.5 & 3.1 & -0.1 & 1.5 \\
\hline & 1979 & -2.9 & 3.2 & -0.4 & -0.1 \\
\hline & 1980 & -2.5 & 3.0 & -0.4 & 0.1 \\
\hline \multirow[t]{3}{*}{ France } & 1978 & 3.7 & -3.9 & 3.0 & 2.8 \\
\hline & 1979 & 1.1 & -1.5 & 2.3 & 1.9 \\
\hline & 1980 & -7.4 & 8.4 & 5.6 & 6.6 \\
\hline \multirow[t]{3}{*}{ Germany } & 1978 & 8.9 & 3.2 & -1.7 & 10.4 \\
\hline & 1979 & -5.3 & 5.7 & -2.8 & -2.4 \\
\hline & 1980 & -16.1 & 3.2 & -2.2 & -15.1 \\
\hline \multirow[t]{3}{*}{ Great Britain } & 1978 & 1.8 & -6.2 & 2.2 & -2.2 \\
\hline & 1979 & -3.3 & -0.2 & 4.9 & 1.4 \\
\hline & 1980 & 6.6 & -8.6 & -0.3 & -2.3 \\
\hline \multirow[t]{3}{*}{ Ireland } & 1978 & -0.3 & 0.3 & 0.1 & 0.1 \\
\hline & 1979 & -1.5 & 0.9 & 0.0 & -0.6 \\
\hline & 1980 & -1.6 & 2.3 & -0.0 & 0.7 \\
\hline \multirow[t]{3}{*}{ Italy } & 1978 & 6.2 & 0.3 & 0.5 & 7.0 \\
\hline & 1979 & 5.1 & -1.8 & 0.1 & 3.4 \\
\hline & 1980 & -9.9 & 12.9 & -2.1 & 0.9 \\
\hline \multirow[t]{3}{*}{ Netherlands } & 1978 & & 0.6 & -0.1 & -0.9 \\
\hline & 1979 & -2.3 & 2.0 & -0.2 & -0.5 \\
\hline & 1980 & -2.8 & 5.3 & -1.5 & 1.0 \\
\hline
\end{tabular}

Source: Bank For International Settlements, Fiftieth Annual Report, 1980, p. 98, and Fifty-First Annual Report, 1981, p. 90.

ing higher real interests after exchange controls had been abolished in late 1979.

\section{Different Terms-of-Trade Effects}

The effects on the balance of payments of the EMS member countries must be considered together with the changes of their terms of trade, which declined in most countries due to the increase in oil prices. The first oil price shock resulted in a negative terms-of-trade effect in 1973-1975 which had been overcome by all countries by 1978, with France, Germany, Great Britain, and Italy even substantially improving their terms of trade. But the next oil price increase in 1979 threw all EMS member countries 
TABLE 6

EC: Terms of Trade, 1971-1980

(Annual Percentage Changes)

\begin{tabular}{|c|c|c|c|c|c|c|c|c|c|c|c|}
\hline & 1971 & 1972 & 1973 & 1974 & 1975 & 1976 & 1977 & 1978 & 1979 & 1980 & $1971-80$ \\
\hline Belgium & -1.4 & 1.3 & 0.7 & -2.7 & -1.0 & -0.9 & 0.3 & -0.2 & 0.1 & -2.7 & -0.7 \\
\hline Denmark & -7.9 & 1.9 & 6.1 & 0.8 & -10.5 & 1.1 & -2.2 & 0.7 & 0.7 & -6.5 & -1.6 \\
\hline France & 1.0 & 2.2 & 0.7 & -13.5 & 4.6 & -1.6 & -2.4 & 3.9 & -0.6 & -6.0 & -1.2 \\
\hline Germany & 2.6 & 1.9 & -5.0 & -5.1 & 5.3 & -2.6 & 0.1 & 4.0 & -3.2 & -4.4 & -0.6 \\
\hline Great Britain & 0.8 & 1.6 & -8.8 & -12.1 & 5.8 & -1.7 & 1.1 & 4.1 & 3.6 & 3.1 & -0.3 \\
\hline Ireland & 1.8 & 6.3 & 5.6 & -15.2 & -1.6 & 3.7 & -1.8 & 1.8 & -3.5 & -8.1 & -1.1 \\
\hline Italy & -1.0 & -1.3 & -8.5 & -13.1 & 4.7 & -2.9 & 1.9 & 3.1 & -1.0 & -5.2 & -2.3 \\
\hline Luxembourg & -7.9 & 1.9 & 6.1 & 0.8 & -10.5 & 1.1 & -2.2 & 0.7 & 0.7 & -4.1 & -1.3 \\
\hline Netherlands & -1.4 & 1.9 & -0.5 & -5.4 & 0.8 & 0.2 & 0.5 & 0.8 & -2.6 & -0.8 & -0.7 \\
\hline
\end{tabular}

Source: European Economy, March 1981, p.p. 94-98. 
(except Great Britain) again into difficulties. Worst hit were France, Germany, Ireland, Italy, Luxembourg, and Denmark in 1980, as can be seen in Table $6{ }^{24}$ Only in Germany did this negative terms-of-trade effect coincide with a higher balance of payments deficit in 1980 .

The likelihood of again improving the terms of trade is less now than after 1973 because the world economy is in recession. With a decreasing or, in some industries, only slowly growing demand, it is hardly possible to push up export prices faster than import prices rise and thus improve the terms of trade. At any rate, the EMS member countries performed in very different ways concerning their terms of trade, depending on their oil import requirements. Great Britain was in the best position with a crude oil import value of only 0.9 percent of GNP in 1980. In the same year this share amounted to 4.0 percent for France and 3.0 percent for Germany. Great Britain not only improved its terms of trade in 1979 and 1980 but will receive estimated revenues of Sterling 6 billion or $\$ 11.25$ billion from its North Sea oil and gas production in 1981 and $1982 .{ }^{25}$ A diverging development of the terms of trade of EMS member countries will create tensions within the currency bloc. Currencies of countries with a relatively strong negative terms of trade change will weaken against the other EMS currencies if not compensated by some other positive factor.

\section{Different Rates of Inflation}

As a consequence of exogenous cost-push effects from the increase of oil and raw material prices, of endogenous cost-push effects from rising wages and administrative costs (taxes, administered prices), and of demand-pull effects from excessive money supply (which is different from country to country) in the EMS, different inflation rates emerge as shown in Table $7 .{ }^{26}$ All EMS member countries as well as Great Britain suffered from the inflationary impact of the oil price increases of 1973 and 1979 but to varying degrees. After 1973 the different countries succeeded in different ways to bring down their inflation rates until 1978. France could reduce its inflation rate in 1978 to only 66.6 percent of its 1974 level. On the other hand, Belgium brought its inflation rate down to 33.6 percent in the same period. The other countries were in between.

Comparing the average level of inflation from 1971 to 1980 in the EMS member countries and Great Britain, one can see that Italy's average inflation rate of 14.7 percent in the group was the 2.8-fold of the German average inflation rate of 5.2 percent, the lowest in the group. Comparing Germany and France as the two economically strongest countries with about the same economic structure, France experienced an 1.8 fold higher average inflation rate. The standard deviation of inflation rates in the group decreased from 6.0 percent in 1975 to 3.4 percent in 1978 and since then has risen continually to 5.3 percent in 1980 . This means that during the era of the EMS the inflation rates between members are drifting apart.

High inflation rate differentials and especially diverging inflation rate differentials change the purchasing power parities. These force a change 
TABLE 7

EC: Inflation Rates, 1971-1980

(Annual Percentage Change in Private Consumption Deflator)

\begin{tabular}{|c|c|c|c|c|c|c|c|c|c|c|c|}
\hline & 1971 & 1972 & 1973 & 1974 & 1975 & 1976 & 1977 & 1978 & 1979 & 1980 & $1971-80$ \\
\hline Belgium & 5.2 & 5.5 & 5.9 & 12.5 & 12.4 & 8.0 & 7.0 & 4.2 & 3.5 & 6.2 & 7.0 \\
\hline Denmark & 7.3 & 8.3 & 10.2 & 14.4 & 10.0 & 9.4 & 10.8 & 9.4 & 9.6 & 11.0 & 10.0 \\
\hline France & 5.5 & 5.9 & 6.8 & 13.2 & 11.4 & 9.9 & 9.2 & 8.8 & 10.5 & 13.5 & 9.4 \\
\hline Germany & 6.0 & 5.6 & 7.5 & 7.1 & 5.9 & 4.4 & 3.9 & 2.6 & 4.0 & 5.4 & 5.2 \\
\hline Great Britain & 8.6 & 6.6 & 8.6 & 17.4 & 23.5 & 15.5 & 15.1 & 8.9 & 12.5 & 16.1 & 13.2 \\
\hline Ireland & 9.4 & 9.6 & 11.6 & 15.8 & 22.3 & 18.7 & 12.7 & 7.2 & 12.2 & 18.2 & 13.7 \\
\hline Italy & 5.5 & 6.4 & 12.4 & 20.9 & 17.6 & 18.1 & 18.2 & 12.8 & 14.9 & 21.2 & 14.7 \\
\hline Luxembourg & 4.7 & 5.2 & 5.0 & 9.9 & 10.2 & 9.5 & 5.8 & 3.5 & 5.8 & 6.3 & 6.6 \\
\hline Netherlands & 8.5 & 8.9 & 9.1 & 10.0 & 10.7 & 8.8 & 5.9 & 4.2 & 4.3 & 6.5 & 7.7 \\
\hline $\begin{array}{l}\text { EC Average } \\
\text { Standard }\end{array}$ & 6.7 & 6.9 & 8.6 & 13.5 & 13.8 & 11.4 & 9.8 & 6.8 & 8.6 & 11.6 & 9.7 \\
\hline Deviation & 1.7 & 1.6 & 2.5 & 4.2 & 6.0 & 4.9 & 4.8 & 3.4 & 4.3 & 5.9 & 3.4 \\
\hline
\end{tabular}

Source: European Economy, March 1981, p.p. 94-98. 
of the par exchange rates. This was shown in an empirical study by G. Basevi, P. Salin, H. E. Scharrer, and N. Thygesen on the EC countries, ${ }^{27}$ which confirmed that in the long run in the EC exchange rate changes corresponded to the purchasing power changes of the various currencies. Therefore, in a monetary system with fixed exchange rates, a realignment of the par rates is unavoidable to restore the purchasing power equivalent of the currencies if inflation rates differ.

\section{INTERNAL TENSIONS AND REALIGNMENTS}

\section{Structural Inequalities}

The basic economic requirements for the establishment of a permanent monetary union are the removal of structural inequalities among the member countries and the coordination of their economic and monetary targets and policy measures to fulfill these targets. Logically this idea was the ramp for the take-off of the EMS. Later, in December 1980, it was stressed by a program of policy coordination to strengthen the EMS in the EC. ${ }^{28}$ Here the EC member countries of the EMS agreed upon the maintenance of convergent monetary and fiscal policy orientations, stronger cooperation between the EC and the United States in monetary and exchange rate policies, and a limited scope of demand-stimulating actions through automatic budget stabilizers, more support for investments, a faster restructuring and energy substitution policy, and improved labor retraining and mobility schemes.

\section{Diverging Economic Behavior}

All these agreements and declarations of the EMS member countries do not alter the fact that indeed a diverging development of inflation rates, interest rates, terms of trade, balances of payments, rates of monetary expansion, and public debt takes place. Some of these factors neutralize each other. Others reinforce each other. These economic data changed the purchasing power parities and inforced a change of the par rates.

High interest rates usually follow from high inflation rates because lenders do not want to lose the purchasing power of their money; rather, they want some gain in real terms from lending money. Interest rates could also be pushed above market level by monetary policy measures if an interest rate differential induces sizable capital exports. This was the case in Germany in 1980 where capital exports to the United States and France took place. The U.S. interest rate differential appeared to be large enough to encourage capital exports from Germany despite the risk of the floating dollar rate. In the case of France, there was a fixed parity between the D-mark and franc in the EMS with little chance of a franc devaluation. Therefore, German capital was lured to France by its high inflationary interest rates although the real interest rate in France was negative by 1 percent in 1979 and by 0.5 percent in 1980. Because of fixed parities 
TABLE 8

EC: Nominal and Real Interest Rates, 1978-1980

\begin{tabular}{lrrrrrr}
\hline & \multicolumn{3}{c}{ Nominal } & \multicolumn{3}{c}{ Real } \\
& 1978 & \multicolumn{1}{c}{1979} & 1980 & \multicolumn{1}{c}{1978} & \multicolumn{1}{c}{1979} & \multicolumn{1}{c}{1980} \\
\hline Belgium & 6.00 & 10.50 & 12.00 & 1.8 & 7.0 & \multicolumn{1}{l}{5.8} \\
Denmark & 14.54 & 15.82 & 17.66 & 5.14 & 6.22 & 6.66 \\
France & 8.96 & 9.48 & 12.99 & 0.16 & -1.02 & -0.51 \\
Germany & 5.80 & 7.40 & 8.50 & 3.20 & 3.40 & 3.10 \\
Great Britain & 12.47 & 12.99 & 13.79 & 3.57 & 0.49 & -2.31 \\
Ireland & 12.83 & 15.07 & 15.35 & 5.63 & 2.87 & -2.85 \\
Italy & 13.70 & 14.05 & 16.11 & 0.90 & -0.85 & -5.09 \\
Luxembourg & 6.64 & 6.78 & 7.50 & 3.14 & 0.98 & 1.20 \\
Netherlands & 7.74 & 8.78 & 10.21 & 3.54 & 4.48 & 3.71 \\
\hline
\end{tabular}

Source: International Monetary Fund, International Financial Statistics, Oct. 1981 (government bond yield), p.p. 78-408. Real interest rates are calculated from nominal interest rates and inflation rates of Table 6.

Germans could repatriate the higher nominal French interests and get a higher real interest rate (of 7.59 percent) than at home where they got only 3.10 percent of real interest in 1980 , as revealed in Table $8 .^{29}$

It also can be seen in Table 8 that Great Britain, Ireland, and Italy produced sizable negative interest rates that would have been even larger if the interest rate of bank saving deposits rather than government bond yield had been chosen as the representative interest rate. The economic consequences were capital outflows from these countries that could have been stopped only by the imposition of capital controls and a prohibition of capital exports.

In the past nominal and real interest rate differentials have caused destabilizing capital flows, pressing on the exchange rates and requiring heavy interventions by the central banks, which in turn created new liquidity and inflationary pressure in the relatively stable countries with strong currencies.

\section{Four Shaky Realignments}

Until the fall of 1981 these tensions made four realignments in the EMS necessary:

—in September 1979: revaluation of the D-mark by 5 percent against the Danish kroner and by 2 percent against all other EMS currencies

-in November 1979: devaluation of the Danish kroner by 4.76 percent against all other EMS currencies

—in March 1981: devaluation of the Italian lira by 6 percent against all other EMS currencies 
-in October 1981: revaluation of the D-mark and the Dutch guilder by 5.5 percent and at the same time devaluation of the French franc and the Italian lira by 3 percent

Although the Belgian franc always moves at its lower "threshold of divergence" and had to be substantially supported by interventions, the Belgian government resisted devaluation as with all former realignments. The reluctance to devalue was based on the presumption that, like the British experience with former devaluations of the pound sterling, a devaluation of the Belgian franc would bring only temporary relief on the currency front. Rising prices of imports following the devaluation would result in an inflationary cost-push effect accelerated by the Belgian indexed wage system. So the Belgian franc will be a source of turmoil in the EMS as long as the Belgian price system and economic structural accommodation process do not work. A similar situation exists in Italy with its wage indexation and the highest inflation rate in the EMS. According to the Bank of International Settlements, 20.3 percent of the inflation rate in Italy was domestically generated and only 3.5 percent imported in $1980 .^{30}$

Reducing the inflationary pressure and self-generating inflationary forces in those EMS member countries with the highest inflation rates will require the abolishment of indexation and employment of better economic policy tools, "policies relating to incomes, energy conservation and substitution, as well as to regulation." ${ }^{31}$ But a strong government is a prerequisite to apply such policies effectively.

In Italy such a strong government cannot be expected. In Belgium structural problems with the steel industry combined with Europe's most liberal unemployment benefits program (currently costing $\$ 3.1$ billion a year), which generates little fear of joblessness, make fighting high inflation rates difficult. ${ }^{32}$ Moreover, Germany and Britain set priority for monetary stability by tight monetary controls whereas France, Belgium, and Denmark value full employment over monetary stability. The latter group of countries try to reach this goal by Keynesian-type pump priming with rising deficits and inflationary effect.

\section{The Handicap of Agricultural Prices}

Another serious obstacle for monetary integration is the complicated "border equalization levies" necessary to maintain national agricultural prices after realignments in the EMS. Prices for agricultural products are fixed in ECU. If one country, for instance France, devalued its currency, the prices of its agricultural products would rise by the devaluation margin and prices for imported agricultural products from other EC countries to France would be cheaper by that margin. This would give a price benefit to the French farmers but also a lower price to agricultural competitors from other EC countries, allowing them to undercut the French prices. To avoid this an intended temporary (but in fact permanent) "border equalization levy" is raised on agricultural imports to France and a subsidy is paid for agricultural exports from France to other EC countries, both by the amount of the devaluation margin. 


\section{Realignment Requires a Political Decision}

If one or several currencies in the EMS come under pressure and a realignment is imperative, the timing as well as the margins of revaluation or devaluation is a political issue. A revaluation of a currency means higher export prices and lower import prices. A devaluation means the opposite. A revaluation will injure especially industries exporting the major share of their production and a sizable share to EC countries. This is the case with the German machinery industry, which exports about 70 percent of its production and about 20 percent of that to France and Italy. The last realignment in October 1981 caused a revaluation effect of the D-mark against the French franc and the Italian lira of 8.76 percent, against all other EC countries of 5.9 percent, and against the rest of the world of 2.3 percent weighed with exports, according to German Federal Minister of Finance Hans Matthöfer. ${ }^{33}$ German banks believe that this realignment came too late and with a too high revaluation margin for the German currency. The correctness of this assumption was validated by immediate movement of the D-mark toward the lower and the French franc toward the upper "threshold of divergence" in the EMS.

\section{EXTERNAL IMPACT}

The EMS is far from being a homogenous currency bloc. Internal tensions built up in the past because of divergent development of the economies and different economic and monetary policies in the member countries. This made four realignments in only two and a half years unavoidable, which is no recommendation for the EMS as a "stable monetary bloc."

Compared with the period of the "mini-snake" in which only the currencies of Belgium-Luxembourg, Denmark, Germany, and the Netherlands were pegged together and all other currencies were floating from March 1976 to March 1979, however, a higher degree of stability of exchange rates between European countries could be reached in the EMS. It comprises a bigger group of countries and obliges them to exercise a higher degree of monetary discipline than before and to hold to the rules of the EMS.

Although two and a half years of EMS performance do not prove much, it is evident from Table $9^{34}$ that the average variation ${ }^{35}$ of the participating currencies in the ECU parity decreased continuously from 15.5 percent in 1978 to 8.7 percent in 1980 and was considerably smaller than the 43.3 percent in 1976, during the period of floating with the heaviest currency speculation that forced the French to leave the "snake." ${ }^{36}$ At the same time the standard deviation of the standard deviations of the various EMS currencies from the average deviation shrank to 8.7 percent in 1980 from 12.0 percent in 1976 and 9.2 percent in 1979 . These statistical data show a stabilizing effect of the EMS as a regional currency bloc compared with the four most important other currencies in the world, the Swiss franc (SF), the 
TABLE 9

EC: Variation of Major Currencies Against the ECU, 1976-1980

\begin{tabular}{lrrrrr}
\hline & 1976 & 1977 & 1978 & 1979 & 1980 \\
\hline BFr/LFr & 38.5 & 6.2 & 11.4 & 8.4 & 9.0 \\
DKr & 33.8 & 32.4 & 7.7 & 32.7 & 4.5 \\
DM & 42.7 & 11.6 & 11.7 & 8.6 & 9.6 \\
FF & 30.1 & 9.6 & 18.0 & 7.4 & 6.1 \\
IR Pd. Sterling & 63.5 & 11.3 & 23.8 & 7.7 & 9.2 \\
Lit & 55.5 & 21.1 & 24.8 & 9.8 & 17.9 \\
hFl & 39.0 & 5.7 & 11.3 & 9.0 & 4.4 \\
\hline Average EMS & 43.3 & 13.9 & 15.5 & 11.9 & 8.7 \\
(unweighted mean) & & & & & \\
Standard Deviation & 12.0 & 5.6 & 6.7 & 9.2 & 4.6 \\
\hline SF & 43.5 & 45.5 & 53.9 & 10.5 & 13.0 \\
UK Pd. Sterling & 63.2 & 11.3 & 23.8 & 32.2 & 44.7 \\
US-\$ & 20.1 & 24.9 & 49.1 & 28.1 & 34.4 \\
Yen & 34.1 & 39.2 & 70.8 & 87.5 & 82.2 \\
\hline Average & & & & & \\
(unweighted mean) & 40.2 & 30.2 & 49.4 & 39.6 & 43.6 \\
Standard Deviation & 18.1 & 15.3 & 19.4 & 33.3 & 28.9 \\
\hline
\end{tabular}

Coefficient of variation (standard deviation of end-of-month rates for each national currency against the ECU divided by the average rate for the year) Results multiplied by 1000 .

Source: European Economy, March 1981, p. 33 (basic figures).

British pound sterling (UK-sterling), the Japanese yen (Yen), and the U.S. dollar (\$). The average of these currencies varied by the 3 -fold in 1979 and by the 5-fold in 1980 of the average of the EMS currencies against the ECU. Among these currencies a very high standard deviation of 33.3 percent in 1979 and 28.9 percent in 1980 was given. Therefore, the regional currency block of the EMS contributed toward a stabilization of the world currency markets.

This is important because in the last decade the world has moved away from the U.S. dollar toward a multicurrency system with a growing share of the EMS currencies. Of all currencies drawn in the International Monetary Fund through October 1981, 28.8 percent had been U.S. dollars; 31.0 percent were currencies of the EMS member countries. In the bloc of EMS currencies almost half (45.5 percent) were D-marks. ${ }^{37}$ European central banks held reserves of 42.9 billion dollars in ECU with changes in world global nongold reserves of 38.2 billion dollars. By the end of 1980 ECU reserves changed by 63.7 billion dollars with world nongold reserves changing by 413.4 billion dollars. ${ }^{38}$

Also, in the international bond markets the EMS currencies gained importance with the D-mark getting the major share. Taking the average of the years 1978 and 1979, 56.8 percent of Euro-bond issues were in U.S. 
dollars and 27.4 percent in D-marks. ${ }^{39}$ Certificates of deposit in ECU were issued by the London-based Lloyd's Bank for the first time in June 1981. The interest rate of these CDs was linked to the interest rate central banks must pay for ECU liabilities. European commercial banks can now settle ECU transactions directly without passing them through a foreign exchange market because the European Investment Bank functions as the source of supply and demand for ECU. ${ }^{40}$

The ECU thus developed as an international reserve and financial instrument characterized by less exchange rate volatility than the U.S. dollar and other non-European currencies. But according to the president of the German Federal Bank, Karl Otto Pöhl, this quality of the ECU is not the way to a future multicurrency system in which the EMS takes a stabilizing role. Instead the EMS should take over this role by its ability to stabilize the structure of currencies in Europe and vis-à-vis other important currencies, primarily vis-à-vis the U.S. dollar. ${ }^{41}$

\section{PROSPECTS}

There is a close relationship between EC political decisions, political cooperation, and progress of the EMS. The foundation of the EMS and the obligation to observe its rules were based on a political decision, as are realignments of the par rates and all further institutional steps such as the creation of a Common European Monetary Fund, the strengthening of the ECU to become the principle reserve asset or even a common European currency, the creation of a common European central bank, and the acceptance of new member countries to the EMS.

On October 24, 1980, the president of the Commission of the European Communities, Roy Jenkins, demanded the fast creation of a European monetary union with a European Monetary Fund bearing the features of a common central bank from inception. Its tasks would be to determine the quantity and time of ECUs issued, to coordinate the exchange rate policies of member countries, and to determine the exchange rate policies vis-à-vis third countries. Jenkins also believes that Great Britain can and must join the EMS. ${ }^{42}$

Such institutional progress certainly would have an impact on the process of European monetary integration through stricter obligations of member countries to exercise monetary discipline and coordinate their economic and monetary policies. Pöhl favors a common supranational institution as the nucleus of a European central bank to which some functions of the national central banks should be transferred..$^{43}$

The political premises for introducing such institutional steps, however, are not yet given. On the contrary, since the end of 1980 monetary and economic policies as well as exchange rates of the EMS member countries are drifting apart. Great Britain is still standing outside the EMS because the Thatcher government is afraid of losing autonomy in its monetary policy. And the elections in France and Greece in 1981 have significantly changed the political landscape. Consequently, no political decision for institutional steps should be expected for several years. 
Even if a conservative government had continued to exist in Greece, the new EC member would not be able to join the EMS because of its extraordinary high inflation rate and its need to restructure and prepare its economy to meet competition in the Common Market. Now with the left wing socialist government declaring its intention to move away from the EC and NATO, a monetary cooperation with the EMS is in the very far future.

The future performance of the EMS will greatly depend on the economic policy coordination between France and Germany, the largest countries with the strongest and most important currencies in the system. The prospects for a closer policy coordination in the future do not look bright. On the contrary, believing that more inflation will not increase employment, Germany will pursue its tight monetary and fiscal policy to keep the inflation rate low. In France, socialist President Francois Mitterrand's prime economic target is to increase employment by:

- public expenditure programs to create jobs

-increasing jobs of civil servants in the public administration

-nationalization of banks and selected industries

These measures will incur modest success in higher employment but certainly will push up the current inflation rate of 13.5 percent by increased deficit spending. The draft budget for 1982 anticipates a peacetime record deficit of $\$ 17.23$ billion, which will be $\$ 2.72$ billion above the expected 1981 deficit. The nationalization of private banks and industries will cost France $\$ 6.35$ to $\$ 8.16$ billion. ${ }^{45}$ These expenses will probably contribute to an even higher deficit. On the other hand, the newly employed people in the public administration and in nationalized enterprises will neither increase productivity nor production. The productivity of the state-owned Regie Renault car manufacturer, for example, is only about half of that of the private-owned Peugeot car manufacturer (which is to be nationalized). So it can be foreseen that inflationary pressure will force France to another devaluation of the franc in 1982.

Italy and Ireland have structural problems, high balance of payments deficits, and no success in bringing down their high inflation rates. Belgium resists necessary devaluations of its currency and, like the Netherlands, Denmark and Italy, has a wage indexation that works as an inflation engine.

\section{CONCLUSION}

Successful monetary integration in a currency bloc with fixed exchange rates and small margins of fluctuation depends on coordinated economic and monetary policies to reach about the same inflation rates at a low level.

Until now the EMS has contributed to a high degree of exchange rate stablization among the participating currencies as well as in the world although its member countries experienced different degrees of inflationary pressures and balance of payments deficits following the second (1979) oil price shock. Beginning in 1981, the development of economic indicators of the EMS member countries, as well as their policies, have 
drifted apart. This will make frequent changes of par rates necessary and the system somewhat shaky.

Nevertheless, the status developed by the EC mitigates against withdrawal even by socialist governments. It is commonly recognized that monetary integration is a necessary accomplishment of economic integration, and the EMS is the logical means for this purpose. Therefore a breakup of the EMS appears improbable, and, after a critical period of some years, a reinforced cooperation with further institutional steps is likely. The ECU will assume a growing importance as a world reserve asset as well as an instrument in the international financial markets. In the stabilization of exchange rates both in the EMS and against the U.S. dollar the D-mark will play a leading role because predominantly asymmetric interventions take place with U.S. dollars and D-marks. Therefore, a basic consent in exchange rate policies and symmetrical interventions of the U.S. and German monetary authorities in accordance with the other EMS central banks will be the basis of a more stable international monetary system.

\section{FOOTNOTES}

* Peter Schaal, Monetäre Theorie und Politik (Munich-Vienna: R. Oldenbourg Verlag, 1981), p. 85 .

2. Commission of the European Communities, European Economy, March 1979, p. 7.

3. Banque de France, "Le Système Monétaire European," Bulletin Trimestriel, no. 30, March 1979.

4. Deutsche Bundesbank, "Das Europäische Währungssystem," Monatsberichte der Deutschen Bundesbank, March 1979.

5. Schaal, Monetäre Theorie, p. 89.

6. European Economy, no. 8, March 1981, p. 8

7. Banque de France, "Le Système Monétaire Européen."

8. European Economy, March 1981, p. 7.

9. Banque de France, "Le Système Monétaire Européen," p. 30.

10. "Stagnierendes Europäisches Währungssystem," Neue Zürcher Zeitung, Sept. 11, 1981.

11. Robert A. Mundell, "Gold Would Serve Into the 21 st Century," Wall Street Journal, Sept. 30, 1981, p. 28.

12. Arthur B. Laffer and Charles W. Kadlec, "The Point of Linking the Dollar to Gold," Wall Street Journal, Oct. 13, 1981, p. 32.

13. Bank for International Settlements, Fifty-First Annual Report, Basel 1981, p. 141.

14. International Monetary Fund, International Financial Statistics, Jan. 1954, pp. 14, 15.

15. Ibid., pp. 20, 230.

16. International Monetary Fund, International Financial Statistics, Sept. 1981, pp. 36, 38.

17. Europe, no. 223, Jan.-Feb. 1981, p. 16.

18. Alexandre Lamfalussy, "Monetary and Fiscal Integration," in Fritz Machlup (ed.), Economic Integration. Worldwide, Regional, Sectoral. London: Macmillan \& Co., 1976, p. 224.

19. European Economy, March 1981, p. 91.

20. Bank for International Settlements. Fifty-First Annual Report, p. 69.

21. Ibid., p. 70.

22. European Economy, March 1981, p. 23.

23. Bank for International Settlements, Fifty-First Annual Report, p. 90, and idem, Fiftieth Annual Report, 1980, p. 98 .

24. European Economy, March 1981, pp. 94-98.

25. Figures calculated from statistics in European Economy, March 1981, p. 89, and International Monetary Fund, International Monetary Statistics, Oct. 1981.

26. European Economy, March 1981, pp. 94-98.

27. G. Basevi, P. Salin, H. E. Scharrer, and N. Thygesen, Optica Report 1976. Inflation and Exchange Rates: Evidence and Policy Guidelines for the European Community, Brussels: Commission of the European Communities, 1977.

28. European Economy, March 1981, p. 10.

29. Source for nominal interest rates: International Monetary Fund, International Monetary Statistics, Oct. 1981, pp. 78, 128, 154, 162, 206, 214, 251, 408. Source for real interest rates: calculated from nominal interest rates and inflation rates of Table 6.

30. Bank for International Settlements, 1981, p. 15.

31. Bank for International Settlements, 1981, p. 26.

32. Jonathan Spivak, "Closing Gates: Unemployment Lines Weave Hopelessness through West Europe," Wall Street Journal, Oct. 4, 1981, pp. 1, 19.

33. Rheinische Post, Oct. 6, 1981.

34. European Economy, March 1981, p. 33 (basic figures).

35. Coefficient of variation (standard deviation of end-of-month rates for each national currency against the ECU divided by average rate for the year). Results multiplied by 1000 .

36. Schaal, Monetäre Theorie, p. 87.

37. International Monetary Fund, International Monetary Statistics, Sept. 1981, p. 22.

38. Bank for International Settlements, 1981, p. 143.

39. Bank for International Settlements, 1981, p. 120.

40. Europe 81, July 1981 , p. 18.

41. Karl Otto Pöhl: "Die Rolle des Europäischen Währungssystems in der internationalen Währungsordnung," Deutsche Bundesbank, Auszüge aus Presseartikeln, No. 11, Frankfurt a.M., Feb. 3, 1981, p. 3.

42. Roy Jenkins: "Das Europäische Währungssystem: Bisherige Erfahrungen und Aussichten für die Zukunft," Europa Archiv, (1981). Cobn 12-16.

43. Pöhl, "Die Rolle des Europäischen Währungssystems."

44. "Common Market Members Realign Currency Rates," Wall Street Journal, Oct. 5, 1981, p. 3. 